\section{Boundary-Crossing Strategies: Managing Macro Policies in a Federal Government}

\author{
Estratégias para Cruzar Fronteiras: Gerenciando Macropolíticas no Governo \\ Federal
}

\author{
Pedro Cavalcante*1 0 \\ Gabriela Spanghero Lotta ${ }^{2}$
}

\section{ABSTRACT}

Objectives: this paper aims to analyze boundary-crossing strategies, henceforth BCS, a complex and relatively new coordination trend in public administration. To do so, we investigated how three prioritized coordination policies from different sectors were designed and implemented in Brazil. Methods: following a literature review on BCS, the paper employs content analysis of the programs' legislation and government white papers. To understand how the programs actually functioned, we interviewed key government stakeholders. Results: they suggest that two macro policies incorporated most of the boundary-crossing features in their formal design and, more importantly, implementation processes. However, the degree to which these characteristics are present varies according to the research focus or the interviewee's position. Conclusions: main findings of BCS strategy are that policy effectiveness and continuity depend on the consensus of different stakeholders about policy goals; the empowerment of leaders; adoption of new coordination instruments; and continuing policy prioritization. Finally, by exploring the adaptation of an international trend to the Brazilian public administration context, the paper shows crucial insights for innovation in terms of policy coordination and implementation.

Keywords: policy implementation; post-new public management; coordination; boundary-crossing strategy.

\section{RESUMO}

Objetivos: este artigo tem como objetivo analisar estratégias de gerenciamento transversal, também denominadas em inglês de boundaries crossing strategies (BCS), uma tendência de coordenação complexa e relativamente nova na administração pública. Para isso, investigamos como, no Brasil, foram elaboradas e implementadas três políticas prioritárias de coordenação em diferentes setores. Métodos: após uma revisão de literatura sobre BCS, o artigo emprega análise de conteúdo da legislação dos programas e documentos oficiais do governo. Para entender como os programas realmente funcionavam, entrevistamos importantes gerentes e dirigentes. Resultados: sugerem que duas das macropolíticas analisadas incorporaram a maioria dos recursos das estratégias de gerenciamento transversal em seus processos de elaboração formal e, mais importante, de implementação. $\mathrm{O}$ grau em que essas características estão presentes, no entanto, varia de acordo com o foco do objeto da pesquisa ou com a posiçáo do ator envolvido. Conclusóes: as estratégias de BCS demonstram que a eficácia e a continuidade das políticas dependem do consenso de diferentes partes interessadas sobre os objetivos das políticas; o empoderamento dos líderes; adoção de novos instrumentos de coordenação; e contínua priorização. Por fim, ao explorar a adaptação de uma tendência internacional ao contexto da administração pública brasileira, o artigo traz percepçôes cruciais para a inovação em termos de coordenação e implementação de políticas públicas.

Palavras-chave: formulação e implementação de políticas públicas; pós-nova gestão pública; coordenação governamental; estratégias de gerenciamento transversal.

\footnotetext{
* Corresponding Author.

1. Instituto de Pesquisa Econômica Aplicada, Brasilia, DF, Brazil.

2. Fundação Getulio Vargas, Escola de Administração de Empresas de São Paulo, São Paulo, SP, Brazil.

Cite as: Cavalcante, P., \& Lotta, G. S. (2021). Boundary-crossing strategies: Managing macro policies in a federal government. Revista de Administração Contemporânea, 25(5), e200012. https://doi.org/10.1590/1982-7849rac2021200012.en

\# of invited reviewers until the decision:
}

\begin{tabular}{|c|c|c|c|c|c|c|c|c|c|}
\hline & 1 & 2 & 3 & 4 & 5 & 6 & 7 & 8 & 9 \\
\hline $1^{\text {st }}$ round & (x) & $\stackrel{\varphi}{2}$ & (x) & $\stackrel{\varphi}{2}$ & & & & & \\
\hline $2^{\text {nd }}$ round & $\stackrel{\varphi}{2}$ & & & & & & & & \\
\hline $3^{\text {rd }}$ round & $\stackrel{\varphi}{2}$ & & & & & & & & \\
\hline $4^{\text {th }}$ round & $\stackrel{\infty}{2}$ & & & & & & & & \\
\hline
\end{tabular}

JEL Code: G38, 118, H83

Editor-in-chief: Wesley Mendes-da-Silva (Fundação Getulio Vargas, EAESP, Brazil) (c) Reviewers: Hironobu Sano (Universidade Federal do Rio Grande do Norte, Brazil) (c) Silvio Luís de Vasconcellos (Escola Superior de Propaganda e Marketing, PPGA, Brazil) (1) Peer Review Report: The Peer Review Report is available at this external URL. Received: January 16, 2020 Received: January 16,2020
Last version received: August 13, 2020 Accepted: August 26, 2020 


\section{INTRODUCTION}

During recent decades, the public sector has experienced the emergence of new strategies to cross boundaries, aiming to improve performance in different ways (Lazzarini, Pongeluppe, Ito, Oliveira, \& Ovanessoff, 2020). Focusing on an integrated view of policymaking as well as strengthening coordination and control mechanisms, these management strategies reflect the opposite view of the original New Public Management (NPM) approach by highlighting the need for reintegration and needs-based holism.

The bulk of the literature agrees that the reasons for the introduction of BCS stem from the excessive organizational fragmentation as a consequence of the NPM reforms, and the increasing complexity of public problems and solutions in the contemporary public governance era (Christensen \& Lægreid, 2007; Dommett \& Flinders, 2015; Elston, MacCarthaigh, \& Verhoest, 2018; Lodge \& Gill, 2011; Pollitt, 2010).

Moreover, the concepts of 'joined-up government,' 'whole-of-government,' 'holistic governance,' 'interactive governance,' and so on, have been implemented to address the 'wicked problems' that challenge the boundaries of public sector organizations, administrative levels, and policy areas (Elston et al., 2018; Ingold, 2018; Lazzarini et al., 2020). The notion of working across boundaries involves inter-organizational, inter-jurisdictional, and inter-sectoral activities, which demand a focus on relational capacity originating from the center of government, and on new ways of policy coordination, including instruments, mechanisms, and decision arenas to address complex problems in administrative settings of multiple state and non-state actors (Elston et al., 2018; Faling, Biesbroek, Karlsson-Vinkhuyzen, \& Termeer, 2019; Ingold, 2018; Lazzarini et al., 2020; Meerkerk \& Edelenbos, 2018).

The majority of scholars investigating these new models of coordination and governance have looked at developed countries (Birrel, 2008; Fossestøl, Breit, Andreassen, \& Klemsdal, 2015; Greve, Laegreid, \& Rykkja, 2016; O’Flynn, Blackman, \& Halligan, 2013; Wegrich, 2009). These studies have been able to draw valuable lessons about these new coordination models, their results, and challenges. However, there are still some gaps in the literature, such as the lack of analysis on less developed countries, and also a lack of studies comparing different policies in the same country (Bouckaert, Peters, $\&$ Verhoest, 2010). Thirdly, a gap arises from the premise that the country's size matters for the coordination models, but this has not yet been sufficiently reported in the literature.

To fulfill these gaps, this paper's primary goal is to comparatively analyze the coordination models of three Brazilian policies in order to assess whether their frameworks are compatible with BCS; the lessons learned about their effectiveness; and outputs and outcomes. Brazil is an interesting case to analyze, because it is a large country, with high territorial diversity, high inequality levels, and a complex political and administrative arrangement. Moreover, Brazil's public administration is characterized by de-centralized authorities, such as the three layers of the federal system; the recent process of empowerment of control bodies; and intense social participation, which imposes significant challenges to federal government for coordinating and achieving effective policy goals (Arantes, Loureiro, Couto, \& Teixeira, 2010; Gomide \& Pires, 2014; Loureiro, Abrucio, Olivieri, \& Teixeira, 2012; Teixeira \& Teixeira, 2019).

The policies were implemented at federal level and are: (a) Plano Brasil Sem Miséria - BSM (Brazil without Poverty Plan); (b) Programa de Aceleração do Crescimento PAC (Growth Acceleration Program); and (c) Plano Brasil Maior - PBM (Greater Brazil Plan). The programs cover initiatives in the social, infrastructure, and economic areas respectively.

We analyzed these cases firstly by investigating whether the management of these prioritized policies in Brazil was in line with the worldwide movement known as BCS. Then, we investigated if and how the programs reached their goals, by examining the different results achieved, focusing in particular on the non-continuity of governance models, and the findings from BCS in relation to highly complex contexts and political instability.

In short, as the literature review will demonstrate, the BCS have been implemented in a variety of developed countries and is well reported by scholars. However, there is still an absence of understanding regarding how they are implemented in undeveloped nations, their differences and similarities in the same government, and how they succeed in a continental country as Brazil, with several political, social, and administrative challenges to coordination efforts. As a result, the paper's findings contribute to the field of study by not only proving that BCS's characteristics are being implemented in the Brazilian public administration, but also introducing key insights for this strategy success. The practical lessons from this inquiry show that the policy effectiveness and stability depend on the consensus of stakeholders about the policy objectives, leaders' empowerment, and the implementation of new and innovative coordination instruments to keep the policy in the priority agenda.

Besides this introduction, the remainder of the paper is as follows. The next section presents the theoretical grounds of BCS, based on a literature review. The third and fourth sections focus on the analysis of the policy cases 
to reach the inquiry's goal and lessons learned. Finally, the paper ends with concluding remarks and recommendations for future research.

\section{LITERATURE REVIEW}

To provide a theoretical basis for the paper's discussions, this section embraces the post-NPM debate and examines the characteristics of BCS in the public sector. In this sense, most of the literature comes from a bibliographical review of reforms in the last decade and the trends in public management in the post-NPM era (Cavalcante, 2017). In this article, the author relies on the analysis of books of renowned publishers in the field of public administration and major international academic journals from 2007 to 2017. In addition, considering the relevance of coordination to understanding BCS, the paper includes some classical and updated literature on this subject. However, it is worth mentioning that other post-NPM trends are also addressed, due to the cross-cutting features of the subject.

From the end of the 1970's to the beginning of the last decade, the New Public Management (NPM) reforms were spread among countries and focus on three main themes: disaggregation, competition, and incentives (Dunleavy, Margetts, Bastow, \& Tinkler, 2006). More recently, a worldwide shift has occurred that reversed these themes. This change started in Anglo-Saxon countries (Christensen \& Lægreid, 2007), as with the original NPM movement, but nowadays it is also identified in other developed countries, for example in Scandinavia (Greve et al., 2016; Lægreid, Sarapuu, Rykkja, \& Randma-Liiv, 2016).

The new movement in public management has different names - 'joined-up government,' 'whole of government,' 'collaborative governance,' and so on - but similar goals and principles, which involve thinking from a boundary-crossing perspective instead of focusing on single-purpose organizations to deal with public sector issues. The strategies, in general, emphasize strengthening a government's capacity of coordination, integrated control, and holistic actions toward the improvement of decisionmaking and policy implementation and delivery (Lazzarini et al., 2020; Lodge \& Gill, 2011; O’Flynn et al., 2013).

So, why has this movement emerged? The literature presents different possible explanations, or as Pollitt (2010) calls them, 'stories.' The recurrent 'fragmentation story' relies on the idea that NPM reforms have pushed central governments to decentralize decision-making and neglect inter-agency coordination. The creation of independent agencies has enhanced operational capacity, and weakened the accountability of government.
This disaggregation process brought negative effects and barriers to public administration in the coordination of public policies, especially those that are cross-sectional (Christensen \& Lægreid, 2007, 2012; Dommett \& Flinders, 2015; Elston et al., 2018; Kolltveit, 2015; Pollitt, 2010). As a consequence, vertical specialization or disaggregation seems to have undermined political control, weakened structural controls, and diminished the real influence of political executives over subordinate institutions and levels; whereas greater horizontal specialization has created challenges for both capacity and coordination (Dommett \& Flinders, 2015; Lægreid et al., 2016).

The 'complexity argument' highlights that governments are facing increasingly complex and ambiguous environments full of so-called 'wicked problems' in public policy (Lodge \& Gill, 2011). In this sense, traditional and departmentalized solutions are no longer able to solve them, demanding cross-boundary initiatives (Elston et al., 2018; Torfing, 2019). As Lam (2005) points out: "Coordination is needed whenever the accomplishment of a task requires the collective effort of a group of actors" (Lam, 2005).

Finally, the last two explanations are: the 'strategic management story,' which argues that these strategies stem from the synergies formed by the need to work together with other organizations, sectors, or levels of government; and the 'better value story,' that sees service outputs and outcomes (effectiveness, efficiency, quality, etc.) as the reasons for incorporating this movement (Pollitt, 2010).

The main assumption relies on the fact that, in the context of the post-NPM era, the center is striking back. In other words, there are attempts to reduce fragmentation and increase control over governmental units based on increasing coordination and control capacity, primarily by empowering and strengthening the center of government to perform these tasks. Greve, Laegreid, and Rykkja (2016) name it as the third generation of reforms focused on more state-centered solutions, while acknowledging the mix of governance mechanisms and institutional complexity. Better coordination means creating more consistency and coherence among decisions both horizontally and vertically. In summary, governments are tending to favor centralized solutions once again.

The first example of this movement is the "joinedup government' (JUG) strategy, initially introduced by Tony Blair's administration in the United Kingdom at the end of the 1990's. The strategy aimed at facing the 'wicked problems' straddling the boundaries of public sector organizations, administrative levels, and policy areas. It was also a response to the increasing fragmentation of the public sector and services. In other words, an opposition to the 'departmentalism,' tunnel vision, and 'vertical silos' 
that were predominant until then (Christensen \& Lægreid, 2007; Pollitt, 2010).

The program goals consisted of integration, capacity, and, especially, horizontal and vertical coordination activities across boundaries, but without removing the boundaries themselves - inter-departmental, central-local, and sectoral (private, public, and non-profit). The purpose was to foster cooperation across and inside government (Birrel, 2008; O'Flynn et al., 2013; Wegrich, 2009). In the UK, an example of JUG was the employment service and welfare benefits operations by the Department for Work and Pensions.

In the United States, the Department of Homeland Security was established to integrate over twenty agencies responsible for policies in different areas, such as antiterrorism, border security, immigration and customs, cyber security, and disaster prevention and management. Another well-known strategy is the 'whole of government' (WOG) strategy, implemented in Australia and New Zealand to engage public service agencies working across portfolio boundaries in order to achieve a shared goal and an integrated government response to particular issues (Pollitt, 2010). Such coordination and control to improve coherence and capacity in the public sector is compatible with the operational mode known as 'joined-up governance' (Boston \& Eichbaum, 2008).

According to Christensen and Lagreid (2007), both approaches focus on policy development, program management, and service delivery, and can be both formal and informal at the same time. Their implementation tends to be a long-term project, normally resulting from several sequential attempts to become established. In this complex and dynamic process, it is usual that the stakeholders acquire knowledge and expertise by policy learning (Christensen \& Lægreid, 2007; Fossestøl et al., 2015; Goldfinch \& Wallis, 2009; Torfing, 2019).

However, in contrast to the NPM reforms, JUG or WOG strategies assume that the goals also depend on strengthening bureaucracy and promoting collaborative and networking actions (Lodge \& Gill, 2011), which part of the literature names as 'boundary spanners' (Ingold, 2018; Meerkerk \& Edelenbos, 2018). Thus, the cooperation must come not only from across government agencies, but also from the relationship among different government levels, private and non-government organizations, both profit and non-profit (Faling et al., 2019; Ingold, 2018; Wegrich, 2009). The underlying idea of 'connecting the dots,' both inside and outside the public sector, normally takes time and involves a trial and error method in policymaking.

In short, as with NPM, BCS must be analyzed as an umbrella movement that describes a variety of initiatives to cope with the problem of governmental fragmentation and complexity in order to promote increasing integration, a holistic view of government, coordination, and capacity. They are not a panacea that will solve all problems everywhere all of the time, and they do not consist of a single coherent set of ideas and tools.

Regarding the main goals, the initiatives go beyond the ordinary public objectives of efficiency and efficacy, as propagated by the initial NPM reforms. This does not mean that these are not addressed, but rather that other dimensions are also considered, such as service quality, social participation, increasing performance, leadership and direction to facilitate delivery and implementation (O'Flynn et al., 2013; Pollitt, 2010).

The emphasis on performance is obviously not a new tool in public administration, but here it takes on a new meaning, since performance has a 'longer time frame,' with a constant monitoring of articulated goals shared by the organizations involved in policymaking, and operated by central government (Goldfinch, 2009; O'Flynn et al., 2013). The overall focus is on a realistic and holistic view of performance-based management (Ejersbo \& Greve, 2016).

The third strategy of the boundary-crossing movement, namely networked or joined-up governance, can be observed in Scandinavian countries (Greve et al., 2016; Kolltveit, 2015). In contrast to NPM logic, the relationship between agencies is based on integration instead of separation; policies are implemented through governance and network control, and not by hierarchical controls (restricted to standard performance management); and organizational integration comes from collaboration between intra- and intergovernmental organizations, substituting for vertical approaches (Fossestøl et al., 2015). However, integration can be affected by political arrangements and agreements (Kolltveit, 2015).

The use of coordination mechanisms calls attention to BCS, because it can include all three possibilities: hierarchical, network, and market, in the sense of applying mixed instruments from traditional, new public management, and post-NPM toward improving service and policy performances.

As Lodge and Gill (2011) argue, these cross-sectoral arrangements in the post-NPM era consist of a mixed pattern of in-house, marketized services and delivery networks; a client-based, holistic management style; boundary-spanning skills; joined-up targets; a procedural focus; impartiality and ethical norms; and stronger centralized control. Nevertheless, the concern about strengthening the capacity of the center, both politically and administratively, does not mean the employment of coordination mechanisms restricted to hierarchy, but also some network and market components 
that show how complex, dynamic, and ambiguous it can be. In these processes, empowering leaderships to nurture longterm and continuous commitment and cooperation among stakeholders and organizations seems crucial (O'Flynn et al., 2013; Peters, 2015).

In short, BCS are very complex and must be analyzed according to a variety of perspectives and purposes. To facilitate understanding of the subject, Figure 1 depicts the main dimensions of BCS, analyzed by the literature discussed above, that will guide the analysis of this research. Firstly, 'Explanations' lists the reasons or 'stories' that scholars use to justify the emergence of BCS. 'Features' then includes the main characteristics that stand out. The third dimension shows the list of the main trends in public management in the post-NPM era (Cavalcante, 2017) and, finally, BCS goals, which are also recurrent in the literature.

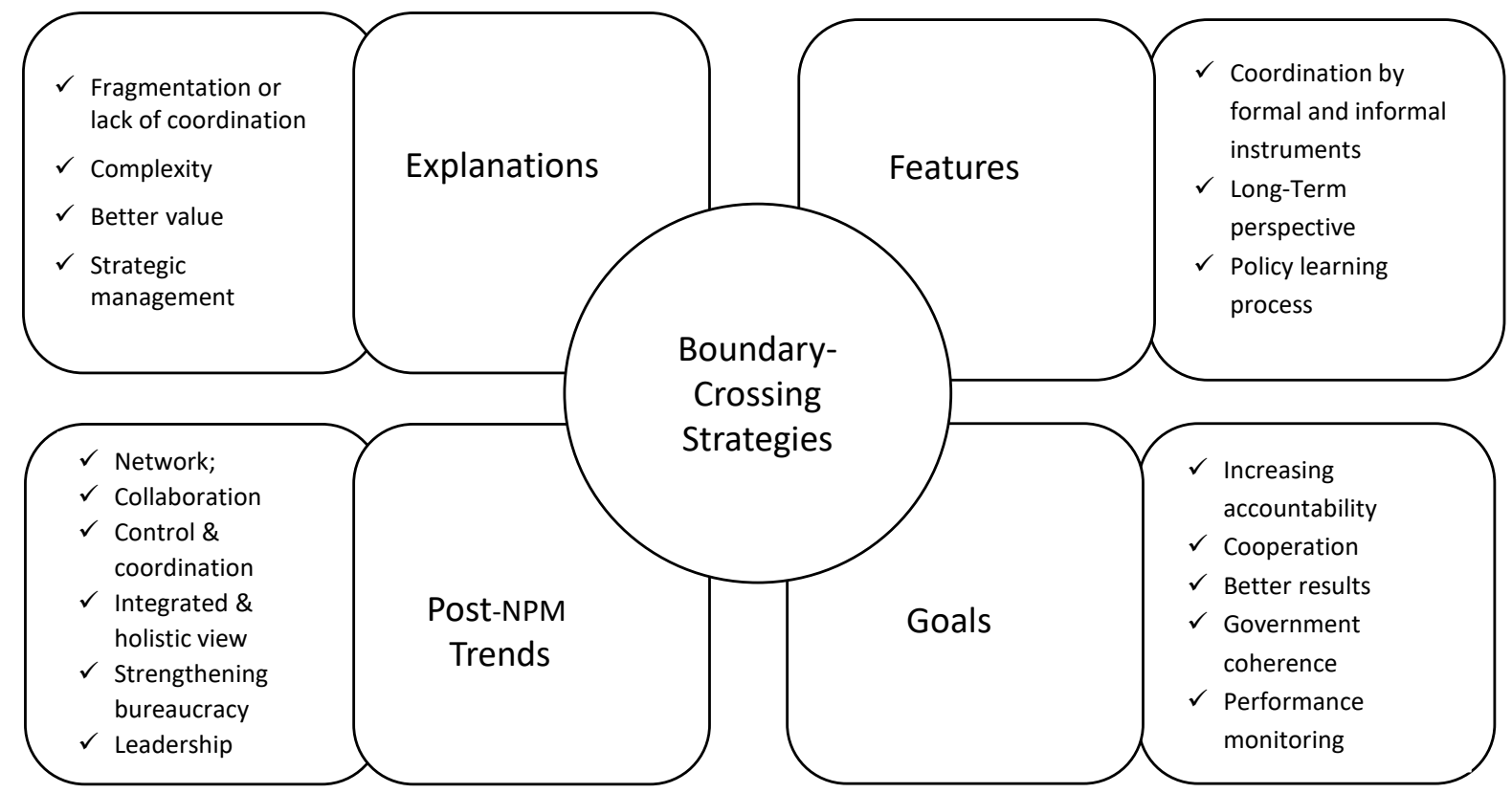

Figure 1. Main dimensions of BCS.

The figure describes the main dimensions of BCS and also details some of the elements pointed out by the literature. Source: own elaboration.

Scholars have also tried to understand what works or not in BCS. For instance, Lam (2005) outlines that coordination would be easy if the division of labor were a simple distribution of activities; if there were a minimal interdependency of activities; if there were a minimal requirement for information on activities; if every actor collaborated with the effort and agreed with the benefits of collective work; and if the environment was sufficiently stable. However, it is almost impossible to meet all of these conditions, and if they were met, there would probably be no need for coordination.

Lazzarini, Pongeluppe, Ito, Oliveira and Ovanessoff (2020), in a comparative analysis of strategies from different countries, propose that the success of these strategies depends on the strong capacity of the state in creating and managing the collaboration between different types of actors. Other authors suggest that the success of collaboration relies on the role of boundary-spanners, and on leaders who are able to create trust in networks or enable innovation in policies (Faling et al., 2019; Meerkerk \& Edelenbos, 2018; Torfing, 2019).

Therefore, there are many risks in these new kinds of reform. Firstly, they demand time and energy; they are also full of unintended consequences. The agendas tend to be too ambitious, especially when they try to confront 'wicked problems.' The tools can generate negative competition instead of positive cooperation. In addition, the adoption of new coordination strategies is a long-term process, involving structural and cultural changes (Christensen \& Lægreid, 2007). In a more recent study, which tries to learn from all of the comparisons already made, Peters (2015) and Torfing (2019) also highlight one very important issue, often neglected by the literature, which is the role of leadership in making coordination efforts work. Peters (2015) also points 
out that the creation of new structures (or structural reform) is not enough to solve coordination problems: they also require a broader view of organizations and the integration of different kinds of instruments.

Based on this theoretical discussion, we will now present the methodology and then analyze the three Brazilian cases.

\section{BCS IN BRAZIL: PAC, BSM, AND PBM}

\section{Methodology}

\section{Case selection and data collection}

Regarding data collection, this paper employs various methods. First, the research team selected macro policies that were government priorities, established in the Pluriannual Plan (Lei n. 12.593, 2012), and that required a new and specific coordination arrangement, and ended after a change in government. From this process we selected three cases to analyze: (a) Plano Brasil Sem Miséria - BSM (Brazil without Poverty Plan); (b) Programa de Aceleração do Crescimento PAC (Growth Acceleration Program); and (c) Plano Brasil Maior - PBM (Greater Brazil Plan). The selection was based on the idea of covering initiatives in the social, infrastructure, and economic areas. Besides that, we also selected programs that were priorities and that were references as innovative institutional arrangements (Gomide \& Pires, 2014; Lotta \& Favareto, 2016).

The researchers then analyzed content from the programs' legislation and official documents (white papers), and subsequently conducted interviews with policy coordinators, and with representatives of other ministries or agencies involved in these policies. The interview guide and the list of respondents are described in the Appendix.

The selection of interviewees focused on the role of their ministries/agencies and on the suggestions of coordinators. The interview script reflects the four dimensions of the boundary-crossing movement, discussed in the paper's theoretical section, namely: program rationale; post-NPM trends; other features; and goals (including results).

Finally, the literature review is based on papers that have already analyzed these policies. We selected articles from prominent journals in the areas of economics, political science, administration, and sociology ${ }^{1}$, as well as from the Capes website, Google Books, and academic productions in the Brazilian Digital Library of Theses and Dissertations ${ }^{2}$, from 2011 to 2020 . The search was based on the programs' names appearing in the papers' titles and abstracts. In addition, the review includes a few articles cited by the managers interviewed.

In general, the research on these macro policies is restricted to a small number of publications, which varies according to when the programs' were in existence. Therefore the oldest program, PAC, is the most cited, followed by BSM and PBM. Due to the complexity and magnitude of these programs, each publication has a different focus, only a few of which concentrate on the policies' management aspects.

\section{Construct and variables}

As this is a qualitative analysis, the variables used to analyze the programs were inspired by the dimensions of the literature proposed in the session of literature review (synthesized in the Figure 1). The used variables were: which are the explanations for the strategy; which are its features; which are the goals of the program; and which are the postNPM trends that can inspire the program. We observed each of the programs trying to understand how they deal with each of these variables and how close or distant they are from the BCS proposals.

\section{Data analysis}

The analysis of the data followed three steps. We first read the papers collected in the literature review and, together with the analysis of the documents, we were able to describe how each program works. Later, we analyzed all interviews transcribed together with the documents and the literature review about the programs in order to observe the main elements that guide the analysis of BCS: reasons for the program, post-NPM trends identified in the program, other features, goals, and results. After coding all the material, we compared the features of the program to the BCS features, in order to understand the alignment between them.

\section{Data validation}

The usage of the three forms of investigation (interviews, documents, and literature review) seems essential because the content analysis tends to be too formal, and the academic publications of these new policies are still in progress. Hence the decision to opt for triangulation, i.e., the combination of different research methods to approach the same phenomenon (Cohen, Mansion, \& Morrison, 2000). In this case, documented, bibliographic analyses and interviews seem appropriate to mitigate issues, such as the lack of information and the intrinsic bias of these multiple sources. Moreover, triangulation helps study a more complex subject under different perspectives in order to map similarities and differences in a complementary way (Denzin, 2006). The analytical framework proposed by Figure 1 enables the 
possibility of replicability of the research. In this sense, scholars may also analyze other policies using the same approach or may check our findings based on different empirical data.

\section{Policy analysis}

In Brazil, the NPM agenda was introduced into the federal government in the first Cardoso administration (1995 to 1998). A special department was created to lead the reform, namely the Ministry of Federal Administration and Reform of the State (Ministério da Administração Federal e da Reforma do Estado - Mare). The Ministry relied on AngloSaxon experiences to make public administration rules more flexible, as a means to supposedly overcome a performance deficit in the Brazilian public sector. However, the plan's ambitious objectives had different results (Rezende, 2004).

During Lula's government (2003-2010), the reform agenda was not prioritized. The government developed strategies for improving workforce policies (mainly creating new careers, recruiting civil servants, and strengthening the school of government); created new models for strategic planning; and invested in new monitoring systems. It was not a formal and integrated agenda, and the government started experimenting with new coordination instruments, which were the basis for the next government (Abrucio, 2007).

During President Dilma Rousseff's first administration (2011-2014), the Brazilian government tried to concentrate its efforts on a few prioritized policies from different areas. The administration launched and prioritized these macro policies to coordinate several ongoing and new programs in the social, economic, and infrastructure sectors (Lotta \& Favareto, 2016; Moretto, 2014; Pires, 2015; Schapiro, 2014).

The government designed complex governance frameworks to cope with the variety of actors, interests, relationships, and in particular coordination instruments aimed at achieving socioeconomic development. Table 1 describes the program's major goals, the leading ministries, and other government agencies involved. It also includes the formal coordination instruments set by their legislation. The objectives of PAC, BSM, and PBM seem convergent with BCS goals.

Table 1. Macro programs' features (goals, coordinator, units involved, and coordination instruments).

\begin{tabular}{|c|c|c|c|c|}
\hline Program & Goals & Coordinator & Ministries/Agencies involved & Coordination Instruments \\
\hline $\begin{array}{l}\text { PAC } \\
\text { (Growth Acceleration } \\
\text { Program) }\end{array}$ & $\begin{array}{l}\text { To increase public investments } \\
\text { in infrastructure, aimed at } \\
\text { improving the quality of public } \\
\text { spending and controlling } \\
\text { the expansion of current } \\
\text { expenditures within the } \\
\text { scope of the Federal Public } \\
\text { Administration. }\end{array}$ & Ministry of Planning & $\begin{array}{l}\text { Ministries of Cities, Health, } \\
\text { Education, Culture, Justice, } \\
\text { National Integration, Transport, } \\
\text { Energy, Defense, Agrarian } \\
\text { Development, and Secretary } \\
\text { of Ports }\end{array}$ & $\begin{array}{l}\text { Committee of Ministers (MP, } \\
\text { MF, and CC) - CGEPAC; } \\
\text { Executive Group (GEPAC); } \\
\text { Growth Acceleration Program } \\
\text { Monitoring System - SisPAC; } \\
\text { Situation Rooms }\end{array}$ \\
\hline
\end{tabular}

\begin{tabular}{|c|c|c|c|}
\hline \multirow{10}{*}{$\begin{array}{l}\text { BSM } \\
\text { (Brazil without Poverty } \\
\text { Plan) }\end{array}$} & \multirow{2}{*}{\multicolumn{3}{|c|}{ To eradicate extreme poverty }} \\
\hline & & & \\
\hline & 1) guarantee of income, for & & $\begin{array}{l}\text { Chiet of Staft Uttice, Secretary- } \\
\text { General; Ministers of Planning, }\end{array}$ \\
\hline & immediate relief from extreme & & Cities, Labor and Employment, \\
\hline & $\begin{array}{l}\text { poverty; 2) access to public } \\
\text { services, to improve the }\end{array}$ & of Social & Agrarian Development, \\
\hline & conditions of education, health, & Development & Health, Education, National \\
\hline & and citizenship of families; 3 ) & & Integration, Energy, Codevasf, \\
\hline & productive inclusion, to increase & & Conab, DNOCS, Embrapa, \\
\hline & capacities and opportunities for & & $\begin{array}{l}\text { FBB, Funasa, ICMBio, Incra, } \\
\text { Sebrae, Petrobras, and BNDES }\end{array}$ \\
\hline & $\begin{array}{l}\text { work and income generation } \\
\text { among the poorest families. }\end{array}$ & & \\
\hline
\end{tabular}

To establish industrial, technological, services, and foreign trade policy for the PBM (Greater Brazil Plan) period 2011 to 2014 , focusing on stimulating innovation and domestic production to leverage the competitiveness of industry in domestic and foreign markets.
Ministry of Chief of Staff Office, Ministry Development Industry and Foreign Trade of Finance, Ministry of Science and Technology, ABDI, BNDES, and Finep
National Council for Industrial Development (CNDI) - level of advice;

Management Committee

- level of management and deliberation;

Sector coordination - level of articulation and formulation (19 sectoral executive committees and nine systemic co-ordinations) 
Based on their initial norms, the programs formally express to some extent the four goals depicted in Figure 1. All of them focus primarily on achieving better results in infrastructure, social, and economic sectors. In short, they appear, at least formally, to demonstrate convergence with $\mathrm{BCS}$, considering their goals and the fact that their designs also include collaboration, coordination, control, and above all - an evident view of integration and holism regarding the public policies in these areas.

The idea of creating new coordination strategies can be seen in the presidential messages from this period (Brasil, 2011b, 2012, 2013). The same boundary-crossing features are identified in the messages of 2014 and 2015 that reinforced the outputs and progress in terms of management, including new mechanisms of transparency and accountability. Similarly, the Multiannual Plan (PPA) brings a communication from the Executive branch whenever submitted to Congress for deliberation. In the PPA 20122015 , it is possible to assume the convergence between BCS characteristics and the macro programs' policymaking, as the excerpt transcribed below demonstrates:

The formulation of large plans such as [BSM], $[\mathrm{PBM}]$, and PAC 2 are examples that show that what is being done involves the improvement of transversal articulation, an essential element to achieve the challenges imposed on policy implementation ... The joint involvement of the public, non-profit and private sectors will be crucial to achieving the objectives related to this macro-challenge (Brasil, 2011b, p. 78-79).

\section{Growth Acceleration Program (PAC)}

The PAC started its second phase in 2012, with efforts to strengthen the management model based on systematic monitoring of project processes and results, coordination with other governmental levels (state and municipalities), and intersectional actions. Thus, the first mention of the PAC program refers to its boundary-crossing and coordination characteristics, followed by an emphasis on control and accountability, which is clear in the sentence "with highlight to the 1,875 control initiatives completed, related to the PAC with systematic monitoring..." (Brasil, 2011a, p. 344).

In the third year of Rousseff's administration, the official document reinforces the cross-sectional nature of the macro programs and outlines some results. Initiatives involving collaboration and partnerships, including civil society, are repeatedly mentioned as the following passage regarding PAC demonstrates: "the Federal Government has been promoting articulated actions with the objective to reduce the infrastructure deficit, especially through planning, regulation, sector oversight, and broadening social control, besides the community's support in policymaking" (Brasil, 2013, p. 272).

Three other publications outline relevant aspects of the PAC features. First, Pires (2015), in the analysis of the mid-level bureaucrats' perceptions of the program, highlights issues of leadership and control. The level of prioritization and political support embedded in the PAC by the Administration is frequently cited as a connected component of implementation. Moreover, the public servants involved refer to the program as a deliberate strategy to improve the government's capacity to coordinate and oversee several cross-sectional projects to help the decisionmaking processes.

Jesus (2011) explores management instruments available, especially the situation rooms, concluding that they help managers make decisions more consciously, based on quality information in different and complementary dimensions of policymaking. Lotta and Favareto (2016) argue that PAC 2 developed an institutional arrangement to monitor based on a logic of integrated and continuous management, seeking to prioritize and guarantee resources, and visibility of over one thousand projects organized in five major policy areas, including housing and transportation. Their findings indicate that PAC's inter-sectoral nature is organized by areas. In other words, formal policy coordination and monitoring are separately conducted, and the relationship with states and local governments relies on an intense degree of verticality with a high level of adaptation to sectoral logic of investments.

PAC perceptions from the interviews are also in line with BCS features. They generally recognize that the program emerged from the state's necessity to address its infrastructure delivery capacity (to generate better value), either due to weaknesses in management (I1) or because of the lack of permanent and substantial budgeting (I2). In this context, besides better results, the interviews indicate that fragmentation and the need for coordination and strategic management could be the reasons for the PAC's creation.

Regarding the post-NPM trends, there is a consensus that the PAC is a consequence of a great effort of coordination and control in the infrastructure actions within the federal government and with the states and municipalities. Although an integrated/holistic view and collaboration/network were not cited as relevant, the respondents stressed the importance of the situation rooms for the program progress. These, in turn, only functioned because of the leadership of the Chief of Staff office and later of the Ministry of Planning, which were empowered by the Presidency to coordinate, demand, and solve problems of implementation in the PAC projects. 
With respect to the strengthening of bureaucracy, the interviewees from the line ministries argued that, based on a diagnosis of weakness in the civil service infrastructure, initiatives were undertaken to build bureaucratic capacity with the injection of new staff and careers in the sector (I2, I3). They agreed that PAC had a learning process, a longterm perspective, and formal coordination instruments. The implementation of the projects also demanded informality, such as regular telephone calls, bilateral talks, or ad-hoc meetings.

Concerning the program objectives and outputs, once again, the interviewees agreed that performance monitoring was the most effective component. The representative of the coordinating ministry argued that the accountability mechanisms, such as the PAC balance reports, had in essence a function of intragovernmental pressure for better performance, while the line ministries' members understood them as one of the significant advantages of the program. Moreover, in terms of cooperation, although the interviewees did not identify explicit mechanisms, they all believed that the best results in PAC projects came from the federal articulations. It generated more coherence in actions, as described in the following passage: "But if you look at Brazil, the level of cooperation has grown dramatically ... it has reduced deadlines and costs that stem from this gain in coherence. And again, these three items: cooperation, better results, and coherence" (I2).

\section{Brazil without poverty (BSM)}

The presidential message also highlighted BSM's focus on an integrated approach and coordination and control dimensions. It improved the management system, the formal cooperation with states and local governments in the Single Register (Cadastro Único), and several social policies (Brasil, 2013, 2014).

Lotta and Favareto (2016) argue that the program's innovation was "the unification of existing policies in a greater strategy, giving them a priority and a constant monitoring process." (Lotta \& Favareto, 2016, p. 53) The authors recognize that BSM is primarily a plan of coordination, monitoring, and evaluation policies undertaken by the three levels of government. Their conclusion also indicates that the plan has a high degree of verticality, similar to PAC, but in terms of its intersectoral nature, the social program can be characterized by juxtaposition without integration.

Moretto (2014) supports the view that BSM is a consequence of inter-ministerial interventions directed at an integrated and holistic approach to a 'wicked problem,' i.e., poverty. Although the Bolsa Familia program has generated tangible outcomes by improving incomes for poorer families, there was a consensus in the federal government that the effective eradication of poverty demanded a broader strategy for social protection. In this context, the formulation of BSM reinforced the instruments for coordination, not only within federal government organizations but also within society and at sub-national levels.

The interviewees reinforced similar perspectives about the program. Notably, BSM arises from its concern with the coordination of actions to confront poverty and overcome the fragmentation of existing policies. Besides this, the complexity of the issue is strongly emphasized, due to the understanding that it cannot be solved with an isolated initiative (I6). In this respect, all of the respondents mentioned the importance of the Single Register (Cadastro Unico) of social policies as a mechanism to integrate a more homogenous view of poverty, and thus, at incorporating a multidimensional perspective of performance. It also had a crucial role in building the holistic and integrated approach, as well as enabling coordination and control of the public policies associated with the program (I14, I5, I6).

In addition, the dynamics of the situation rooms are seen not only as a systematic way of monitoring such actions but also as an arena of network formation and collaboration. In this sense, Interviewee 4 points out

"a space that sealed and created this culture (of collaboration) were the situation rooms, conducted with a characteristic of pressure, as well as of cooperation; there was that balance if the pressure was discussed, but also offered support if things were not going well."

Of course, the leadership, with the empowerment of the MDS and its bureaucracy by the Presidency to lead the BSM, was also cited, since the Administration's logo was 'a rich country is a country without poverty.'

Regarding other features, it is worth noting that BSM does not have a long-term perspective, as it was conceived for a four-year period (I4, I5). Nevertheless, the respondents agreed that their implementation could be a process of continual learning, as well as the constant use of informal coordination tools and those established by the program's legislation.

Finally, in the analysis of the objectives mapped in the BCS literature, the perception of those involved with BSM is that goals and results, in different measures, are also observed in the program's implementation. According to Interviewee 4, "the first objective was to increase impact (better value). The second was government coherence. The third was cooperation. The fourth was accountability." It is worth mentioning that accountability was a way for more transparency to the data and to expand the relationship with 
civil society, especially during the so-called 'Brazil Dialogues without Poverty' (I5).

\section{Greater Brazil plan (PBM)}

PBM had substantial differences in comparison to PAC and BSM. First, its purpose was the need to deliver better values or outputs to the country in terms of competitiveness, productivity, and innovation. Moreover, because it faced a complex subject, the nature of policy issues and fragmentation are also the reason for its creation.

Schapiro (2014) emphasizes the plan's weakness in the capacity of both the administrative and political dimensions of its institutional arrangement. Formally, the PBM design in books, as he named, appears to be a proposal for an interactive and transforming industrial policy. However, in reality, it departed from its goals. Despite the creation of many formal coordination instruments that would supposedly support the proposal above, Schapiro (2014) argues that the lack of empowerment and decisionmaking capacity in an agency (ABDI) responsible for the program coordination and implementation prevented the planned outputs and outcomes effectiveness. He argues that "the industrial policy still suffers from a decision-making cacophony, provided by a holistic institutional arrangement, with representatives of various ministries, but without formal and material decision-making centrality. There is, therefore, a problem of intra-governmental coordination" (Schapiro, 2014, p. 49).

In fact, in the analysis of PBM alignment with postNPM trends, limitations arise as regards framing it within the scope of BCS. Undoubtedly, everyone agreed that the program's formal design emphasized coordination and control as central components. The leadership by a parallel agency, outside the core of government, was seen as a major barrier to articulation and cooperation between the organizations involved (I7, I8, I9).

Although therewas recognition of ABDI'scoordination and monitoring efforts, they were restricted to operational levels only. Besides, divergences in substantive aspects of the industrial policy, especially regarding tax benefits, have undermined the program's capacity to build a holistic and integrated view of PBM during Rousseff's administration. In this sense, Arbix, Salerno, Amaral and Lins (2017) highlight the program's importance as part of a government strategy, known as 'state activism' - a combination of regulatory modernization and unprecedented public support for research and technology in the private sector. But indeed, its implementation can be characterized by contradictions that undermined its effectiveness.

Regarding the program's objectives and results in management, interviewees reinforced the negative perspective of strategy achievement, as well as its disparity with BCS components. Nonetheless, they agreed that almost nothing had been accomplished, except for internal cooperation, the strengthening that has culminated in the creation of the 'MDIC system' (I7).

In short, the search for better results and coherence was affected by the internal differences in the government regarding the initiatives, as well as by the unfavorable macroeconomic environment. Finally, the failure to implement the coordination instruments contributed to the impossibility of building cooperation among stakeholders and agencies involved in the PBM management core.

\section{Characteristics of the programs and BCS}

Based on official publications, policy literature, interviews, and as summarized in Table 2 below, this paper has demonstrated that PAC and BSM aggregated most of the BCS features into both their formal design and, more importantly, implementation processes. The degree to which these characteristics are present in the programs may vary according to the research subject's focus or the stakeholder position. Policymakers or coordinators tend to have a broader and more positive view about the programs' attributes.

Nevertheless, the inquiry findings support the conclusion that the PAC and BSM programs are in line with BCS. In contrast, the PBM's content analysis and interviews reinforced the barriers and difficulties the program faced, as already mapped by its evaluative studies. In this respect, the program was far from being compatible with the basis of an effective BCS, especially during its implementation phase.

\section{LESSONS LEARNED}

There are a number of essential findings to be learned by analyzing these cases. First, coordination effectiveness depends on a consensus around the policy agenda. PAC and BSM are both examples of social and governmental agreement about policy content and the need to prioritize them in the public agenda, which was not replicated in the case of the PBM program. In this case, neither the market nor the ministries and agencies agreed with the solutions proposed by the program. If the literature already points out the difficulties of coordination when there is consensus, it is even more difficult to effectively coordinate resources, efforts, and units in a context without convergence among stakeholders.

The second lesson is that coordination depends on the actors' empowerment. As concluded before by Bouckaert, Peters, and Verhoest (2010), the influence of the ministry is crucial for promoting coordination - as was the case with 
Table 2. Characteristics of the programs (PAC, BSM, and PBM) and boundary-crossing strategies.

\begin{tabular}{|c|c|c|c|c|c|}
\hline Program & Reasons & Post-NPM trends & Other features & Goals and results & BCS alignment \\
\hline $\begin{array}{l}\text { PAC } \\
\text { (Growth } \\
\text { Acceleration } \\
\text { Program) }\end{array}$ & $\begin{array}{l}\text { Fragmentation and lack of } \\
\text { coordination; better value; } \\
\text { strategic management. }\end{array}$ & $\begin{array}{l}\text { Collaboration; control } \\
\text { and coordination; } \\
\text { integrated and holistic } \\
\text { view; strengthening; } \\
\text { bureaucracy; leadership. }\end{array}$ & $\begin{array}{l}\text { Coordination by formal } \\
\text { and informal instruments; } \\
\text { long-term perspective; } \\
\text { policy learning process; } \\
\text { trial and error process. }\end{array}$ & $\begin{array}{l}\text { Cooperation; better } \\
\text { results; government } \\
\text { coherence; performance } \\
\text { monitoring. }\end{array}$ & YES \\
\hline $\begin{array}{l}\text { BSM } \\
\text { (Brazil without } \\
\text { Poverty Plan) }\end{array}$ & $\begin{array}{l}\text { Fragmentation and lack of } \\
\text { coordination; complexity; } \\
\text { better value; strategic } \\
\text { management. }\end{array}$ & $\begin{array}{l}\text { Collaboration; control } \\
\text { and coordination; } \\
\text { integrated and holistic } \\
\text { view; strengthening; } \\
\text { bureaucracy; leadership. }\end{array}$ & $\begin{array}{l}\text { Coordination by formal } \\
\text { and informal instruments; } \\
\text { policy learning process; } \\
\text { trial and error process. }\end{array}$ & $\begin{array}{l}\text { Increasing accountability; } \\
\text { cooperation; better results; } \\
\text { government coherence; } \\
\text { performance monitoring. }\end{array}$ & YES \\
\hline $\begin{array}{l}\text { PBM } \\
\text { (Greater Brazil } \\
\text { Plan) }\end{array}$ & $\begin{array}{l}\text { Fragmentation and lack of } \\
\text { coordination; complexity; } \\
\text { better value. }\end{array}$ & $\begin{array}{l}\text { Control and coordination } \\
\text { (operational level). }\end{array}$ & $\begin{array}{l}\text { Policy learning (restricted } \\
\text { to the MDIC system). }\end{array}$ & Performance monitoring & $\mathrm{NO}$ \\
\hline
\end{tabular}

Note. The table synthesizes the features of the boundary-crossing strategies (discussed in the literature review section) present in the three macro policies. The final column (BCS alignment) reiterates that PBM's implementation is the only one that is not in line with the BCS. Source: own elaboration.

PAC, which was coordinated by the Ministry of Planning. However, a non-central ministry can also be in charge as the President offers conditions and empowerment, as the example of the Ministry of Social Development. During the BSM implementation, MDS was the President's priority, with a direct communication line and sufficient resources to lead the coordination designated for many policies.

On the contrary, the institutional arrangement of PBM, with the non-central agency responsible and without empowerment, provoked a lack of instruments to enforce adherence and residual engagement from the other stakeholders. These findings suggest the importance of the concept of polycentrism (Batjargal et al., 2013; Ostrom, 2010, 2005). That is, institutions may be originated in different sources of power, which demands that some actors perform as entrepreneurs or boundary-spanners in order to enable coordination (Faling et al., 2019; Ingold, 2018).

The third lesson is that new types of coordination depend on original instruments, and if these are not sufficiently established, they are based on voluntary or transitory adherence and empowerment. The three cases show incremental changes based on parallel kinds of instruments that did not face radical, political (Bouckaert et al., 2010), or cultural modifications (Christensen \& Lægreid, 2007). When empowerment ends, the coordination system tends to die, which happened in all three of the programs. When a new president took office, attention to the coordination systems weakened, and they were progressively forgotten due to the lack of use.

In the PAC and BSM cases, the content of the policies (social policies and infrastructure projects) remained, although the coordination system did not. In contrast, in the PBM case, the policy content was substituted with new priorities. Almost all of the instruments of coordination ended, which indicates that they were not sufficiently established in the first place. As Bouckaert et al. (2010) and Peters (2015) previously concluded, some of the new instruments are very hard to implement, as they lack clarity about responsibilities, and have low capacity in terms of enforcement. As a consequence, there is a learning process based on errors and trials, as already highlighted in the literature (Christensen \& Lægreid, 2007; Faling et al., 2019; Fossestøl et al., 2015; Goldfinch \& Wallis, 2009; Ingold, 2018; Torfing, 2019; Wegrich, 2009).

Considering these findings, we can learn another lesson: coordination policies die when prioritization no longer persists; when empowerment ends (or is not strong enough); and when instruments are not sufficiently established, depending instead on voluntary use and very transitory adherence. This occurred in the three programs analyzed, except for one instrument: Cadunico, which is well-established and is used as a database for 32 different policies. This specific instrument assumed a role for articulating policies, even when the coordination strategy no longer existed.

\section{FINAL REMARKS}

This paper aimed to analyze BCS by focusing on the coordination efforts in very complex, new, and unsustainable cases. We investigated how three high-priority Brazilian macro policies, BSM, PBM, and PAC, were designed and implemented. The paper employed different methodological approaches: content analysis of the programs' legislation and government white papers; a literature review; and interviews with key managers to understand how the programs 
functioned. This triangulation of methods helped compare the programs with the characteristics of BCS through different and complementary perspectives.

As a result, the PAC and BSM's policymaking seemed quite in line with most of the boundary-crossing features: both their formal design and implementation processes. Regarding the lessons from these experiences, we argue that the policy effectiveness and continuity depend on the consensus of different stakeholders about shared values and goals; political empowerment to the unit in charge of coordination; institutionalization of new coordination instruments; and continuing policy prioritization.

It is worth noting the original value of this article, as it addresses a discussion that has not yet matured in the field. Nevertheless, the efforts to build macro public policies in the Brazilian federal government show signs of similarity with the characteristics of BCS. These strategies, as well as policies and management initiatives in the country, even though still in the development stage, seek to deal with the same challenges. They have arisen to address the consequences of NPM reforms to adapt to constant social, economic, and technological changes, to respond to increasing social pressures and demands for better public services, as well as to prepare to deal with 'wicked problems.'

Notably, the research has some limitations due to the still incipient and unorganized knowledge of BCS, as well as the low level of scientific basis regarding the programs analyzed and their effective outputs and outcomes. However, it is worth mentioning that the cases seem very appropriate for this inquiry since the Brazilian public administration has institutional and political characteristics that continuously challenge the federal government to innovate in terms of policy coordination and implementation.

\section{REFERENCES}

Abrucio, F. L. (2007). Trajetória recente da gestão pública brasileira: Um balanço crítico e a renovação da agenda de Reformas. Revista de Administração Pública - RAP, 41(spe), 67-86. https://doi.org/10.1590/S0034-76122007000700005

Arantes, R. B., Loureiro, M. R., Couto, C., \& Teixeira, M. A. C. (2010). Controles democráticos sobre a administração pública no Brasil: Legislativo, tribunais de contas, Judiciário e Ministério Público. In M. R. Loureiro, F. L. Abrucio, R. S. Pacheco (Eds.), Burocracia e política no Brasil: Desafios para o estado democrático no século XXI. Rio de Janeiro: FGV Editora.
As a future research recommendation, one alternative is to investigate how the BCS debate has been incorporated or diffused into other levels of government, and how this compares with other countries. From a methodological perspective, it would be interesting to employ survey techniques to capture public service perceptions about the subject from a broader perspective.

\section{ACKNOWLEDGMENTS}

We would like to thank Isabella Goellner, Noelle Silva, and Jaqueline Borges for assisting this research, Miriam Price for the proofreading of the manuscript, and the RAC's editor and reviewers for the comments and suggestions to the paper.

\section{ENDNOTES}

1. Revista Brasileira de Economia and Revista de Economia Politica; Dados, Revista Brasileira de Ciências Sociais, Opiniáo Pública, Brazilian Political Science Review, and Revista Brasileira de Ciência Política; Revista de Administração Contemporânea, Organização e Sociedade, Brazilian Administration Review, and Revista de Administração Mackenzie; Revista de Administração da Universidade de Sáo Paulo; Novos Estudos Cebrap and Revista de Sociologia.

2. For researching papers, we used http://www.periodicos. capes.gov.br/. https://books.google.com.br/ provided a way to initially identify books that fit in the descriptors. After that, we looked for the books in libraries and the ones available online. Finally, http://bdtd.ibict.br/vufind/ for dissertations and theses.
Arbix, G., Salerno, M. S., Amaral, G., \& Lins, L. M. (2017). Avanços, equívocos e instabilidade das políticas de inovação no Brasil. Novos estudos CEBRAP, 36(3), 9-27. https://doi.org/10.25091/s0101-3300201700030002

Batjargal, B., Hitt, M. A., Tsui, A. S., Arregle, J.-L., Webb, J. W., \& Miller, T. L. (2013). Institutional polycentrism, entrepreneurs' social networks, and new venture growth. Academy of Management Journal, 56(4), 1024-1049. https://doi.org/10.5465/amj.2010.0095 
Birrell, D. (2008). The final outcomes of the review of public administration in Northern Ireland. Tensions and compatibility with devolution, parity and modernization. Public Administration, 86(3), 779-793. https://doi.org/10.1111/j.1467-9299.2008.00725.x

Boston, J., \& Eichbaum, C. (2008). Financial management and democratic accountability: Lessons from New Zealand. In M. Ezzamel, N. Hyndman, Å. Johnsen \& I. Lapsley (Eds.), Accounting in politics: Devolution and democratic accountability. London: Routledge

Bouckaert, G., Peters, B. G, \& Verhoest, K. (2010). The coordination of public sector organizations. New York: Palgrave Macmillan Hampshire.

Brasil. (2011a) Plano plurianual - PPA 2012-2015. Ministério do Planejamento, Orçamento e Gestão: Secretaria de Planejamento e Investimentos Estratégicos. Brasília, DF, Brazil. Retrieved from https:/www.gov.br/economia/ $\mathrm{pt}-\mathrm{br} / \mathrm{assuntos} / \mathrm{planejamento/plano-plurianual-ppa/ppa-}$ 2012-2015

Brasil. (2011b). Mensagem ao congresso nacional. Presidência da República do Brasil. Brasília. Retrieved from http:// www.biblioteca.presidencia.gov.br/publicacoes-oficiais/ mensagem-ao-congresso-nacional/mensagem-aocongresso-nacional-dilma-rousseff-2011.pdf/view

Brasil. (2012). Mensagem ao Congresso Nacional. Presidência da República do Brasil. Brasília. Retrieved from http:// www.biblioteca.presidencia.gov.br/publicacoes-oficiais/ mensagem-ao-congresso-nacional/mensagem-aocongresso-nacional-dilma-rousseff-2012/view

Brasil. (2013). Mensagem ao Congresso Nacional. Presidência da República do Brasil. Brasília. Retrieved from http:// www.biblioteca.presidencia.gov.br/publicacoes-oficiais/ mensagem-ao-congresso-nacional/mensagem-aocongresso-nacional-dilma-rousseff-2013/view

Brasil. (2014). Mensagem ao Congresso Nacional. Presidência da República do Brasil. Brasília. Retrieved from http:// www.biblioteca.presidencia.gov.br/publicacoes-oficiais/ mensagem-ao-congresso-nacional/mensagem-aocongresso-nacional-dilma-rousseff-2014/view

Cavalcante, P. (2017). Gestão pública contemporânea: Do movimento gerencialista ao pós-NPM. Brasília: Instituto de Pesquisa Econômica Aplicada-IPEA.

Christensen, T., \& Lægreid, P. (2007) The whole-ofgovernment approach to public sector reform. Public Administration Review, 67(6), 1059-1066. https://doi.org/10.1111/j.1540-6210.2007.00797.x

Christensen, T., \& Lægreid, P. (2012). Competing principles of agency organization: The reorganization of a reform. International Review of Administrative Sciences, 78(4), 579596. https://doi.org/10.1177\%2F0020852312455306

Cohen, L., Mansion, L., \& Morrison, K. (2000). Research methods in education ( 5 ed.). London: Routledge.

Denzin, N. K. (2006). Sociological methods: A sourcebook (1st ed.). New York: Routledge.
Dommett, K., \& Flinders, M. (2015). The centre strikes back: Meta-governance, delegation, and the core executive in the United Kingdom, 2010-14. Public Administration, 93(1), 1-16. https://doi.org/10.1111/padm.12121

Dunleavy, P., Margetts, H., Bastow, S., \&Tinkler,J.(2006). Newpublic management is dead - long live digital-era governance. Journal of Public Administration Research and Theory, 16(3), 467-494. https://doi.org/10.1093/jopart/mui057

Ejersbo, N., \& Greve, C. (2016). Relevance of management instruments. In C. Greve, P. Lægreid, \& L. H. Rykkja (Eds.), Nordic administrative reforms: Lessons for public management (pp. 129-144). London: Palgrave Macmillan.

Elston, T., MacCarthaigh, M., \& Verhoest, K. (2018). Collaborative cost-cutting: Productive efficiency as an interdependency between public organizations. Public Management Review, 20(12), 1815-1835. https://doi.org/10.1080/14719037.2018.1438498

Faling, M., Biesbroek, R., Karlsson-Vinkhuyzen, S., \& Termeer, K. (2019). Policy entrepreneurship across boundaries: A systematic literature review. Journal of Public Policy, 39(2), 393-422. https://doi.org/10.1017/S0143814X18000053

Fossestøl, K., Breit, E., Andreassen, T. A., \& Klemsdal, L. (2015). Managing institutional complexity in public sector reform: Hybridization in front-line service organizations. Public Administration, 93(2), 290-306. https://doi.org/10.1111/padm.12144

Goldfinch, S. \& Wallis, J. L. (2009). International handbook of public management reform. Cheltenham: Edward Elgar Publishing.

Goldfinch, S. (2009). New Zealand: Reforming a new public management exemplar? In S. Goldfinch, \& J. L. Wallis (Eds.), International handbook of public management reform (chap. 9). Cheltenham: Edward Elgar Publishing.

Gomide, A., \& Pires, R. (2014). Capacidades estatais e democracia: $A$ abordagem dos arranjos institucionais para análise de politicas públicas. Brasília: Instituto de Pesquisa

Greve, C., Lægreid, P., \& Rykkja, L. H. (2016). Nordic administrative reforms: Lessons for public management. London: Palgrave Macmillan.

Ingold, J. (2018). Employer engagement in active labour market programmes: The role of boundary spanners. Public Administration, 96(4), 707-720. https://doi.org/10.1111/padm.12545

Jesus, M. S. (2011). Estudos das necessidades de informação dos coordenadores da sala de situação do Programa de aceleração do crescimento (PAC) (Master thesis). Universidade de Brasília, Brasília, DF, Brazil.

Kolltveit, K. (2015). Strengthening of the executive center: Looking beyond NPM as the explanation for change. International Review of Administrative Sciences, 81(1), 18-36. https://doi.org/10.1177\%2F0020852314541566

Lægreid, P., Sarapuu, K., Rykkja, L., \& Randma-Liiv, T. (2016). Organizing for coordination in the public sector: Practices and lessons from 12 European countries. London: Palgrave MacMillan 
Lam,W.F.(2005).Coordinating thegovernmentbureaucracyin Hong Kong: An institutional analysis. Governance, 18(4), 633654. https://doi.org/10.1111/j.1468-0491.2005.00295.x

Lazzarini, S., Pongeluppe, L., Ito, N., Oliveira, F., \& Ovanessoff, A. (2020). Public capacity, plural forms of collaboration, and the performance of public initiatives: A configurational approach. Journal of Public Administration Research and Theory, 30(4), 579-595. https://doi.org/10.1093/jopart/muaa007

Lei no 12.593 , de 18 de janeiro de 2012. (2012). Institui o plano plurianual da união para o período de 2012 a 2015. Diário Oficial da União, Brasília, DF: Ministério do Planejamento, Orçamento e Gestão.

Lodge, M., \& Gill, D. (2011). Toward a new era of administrative reform? The myth of post-NPM in New Zealand. Governance, 24(1), 141-166. https://doi.org/10.1111/j.1468-0491.2010.01508.x

Lotta, G., \& Favareto, A. (2016). Desafios da integração nos novos arranjos institucionais de políticas públicas no Brasil. Revista de Sociologia e Politica, 24(57), 49-65. https://doi.org/10.1590/1678-987316245704

Loureiro, M. R., Abrucio, F. L., Olivieri, C., \& Teixeira, M. A. C. (2012). Do controle interno ao controle social: A múltipla atuação da CGU na democracia brasileira. Cadernos Gestão Pública e Cidadania, 17(60), 54-67. https://doi.org/10.12660/cgpc.v17n60.3980

Meerkerk, I. V., \& Edelenbos, J. (2018). Facilitating conditions for boundary-spanning behaviour in governance networks. Public Management Review, 20(4), 503-524. https://doi.org/10.1080/14719037.2017.1302248

Moretto, A. J. (2014). Brazilian strategy against poverty: the bolsa familia and Brazil sem miséria. In K. Fakier, \& E. Ehmke (Orgs.), Socio-Economic Insecurity in Emerging Economies (pp. 160-174). London: Routlege/Eathscan

O’Fynn, J., Blackman, D., \& Halligan, J. (2013). Crossing boundaries in public management and policy: The international experience. London: Routledge.

Ostrom, E. (2005). Understanding institutional diversity. Princeton, NJ: Princeton University Press.
Ostrom,E.(2010). Beyond marketsandstates: Polycentricgovernance of complex economic systems. American Economic Review, 100(3), 641-672.https://doi.org/110.1257/aer.100.3.641

Peters, B. G. (2015). Pursuing horizontal management: The politics of public sector coordination. Lawrence, KS: University Press of Kansas.

Pires, R. R. C. (2015). Por dentro do PAC: Dos arranjos formais às interaçóes e práticas dos seus operadores. In P. Cavalcante, G. Lotta. (Orgs.), Burocracia de médio escalão: Perfil, trajetória e atuaçâo (pp. 177-222). Brasília: Escola Nacional de Administração Pública - ENAP.

Pollitt, C. (2010). Simply the best? The international benchmarking of reform and good governance. In J. Pierre, P. W. Ingraham (Eds.), Comparative administrative change and reform: Lessons learned (pp. 91-113). Kingston: McGillQueen's University Press.

Rezende, F. C. (2004). Por que falham as reformas administrativas? Rio de Janeiro: Editora FGV.

Schapiro, M., (2014). Ativismo estatal e industrialismo defensivo: Instrumentos e capacidades na política industrial brasileira. In A. Gomide, R. Pires. (Orgs.), Capacidades estatais e democracia: Arranjos institucionais de politicas públicas. Rio de Janeiro: Instituto de Pesquisa Econômica Aplicada IPEA. Retrieved from https://direitosp.fgv.br/node/87826

Teixeira, L. R., \& Teixeira, M. A. C. (2019). Arquitetura da participação social no Brasil: Um espaço em construção. Revista Iberoamericana de Estudios Municipales, (20), 3357. https://doi.org/10.4067/S0719-17902019000200033

Torfing, J. (2019). Collaborative innovation in the public sector: The argument. Public Management Review, 21(1), 1-11. https://doi.org/10.1080/14719037.2018.1430248

Verhoest, K., Bouckaert, G., \& Peters, B. G. (2007). Janus-faced reorganization: Specialization and coordination in four OECD countries in the period 1980-2005. International Review of Administrative Sciences, 73(3), 325-348. https://doi.org/10.1177\%2F0020852307081144

Wegrich, K. (2009). The administrative burden reduction policy boom in Europe: Comparing mechanisms of policy diffusion [Discussion Paper 52]. Centre for Analysis of Risk and Regulation, London School of Economics and Political Science, London, UK. 


\section{Authorship}

\section{Pedro Cavalcante*}

Instituto de Pesquisa Econômica Aplicada

SBS, Quadra 1, Bloco J, Sala 1211, 70076-900, Brasília, DF, Brazil

E-mail address: cavalcante.pedro@gmail.com

(D) https://orcid.org/0000-0001-7635-695X

\section{Gabriela Spanghero Lotta}

Fundação Getulio Vargas, Escola de Administração de Empresas de São Paulo

Av. 9 de julho, no 2029, 01313-902, Bela Vista, São Paulo, SP, Brazil.

E-mail address: gabriela.lotta@gmail.com

(D) https://orcid.org/0000-0003-2801-1628

* Corresponding Author

\section{Funding}

The authors state that there are no funders to report for this article.

\section{Conflict of Interests}

The authors have stated that there is no conflict of interest.

\section{Copyrights}

RAC owns the copyright to this content.

\section{Authors' Contributions}

$1^{\text {st }}$ author: conceptualization (lead); data curation (lead); investigation (lead); methodology (equal); writing-original draft (equal); writing-review \& editing (equal).

$2^{\text {nd }}$ author: conceptualization (supporting); data curation (supporting); investigation (supporting); methodology (equal); writing-original draft (equal); writing-review \& editing (equal).

\section{Plagiarism Check}

The RAC maintains the practice of submitting all documents approved for publication to the plagiarism check, using specific tools, e.g.: iThenticate.

\section{Peer Review Method}

This content was evaluated using the double-blind peer review process. The disclosure of the reviewers' information on the first page is made only after concluding the evaluation process, and with the voluntary consent of the respective reviewers.

\section{Data Availability}

The authors claim that the data used in this article is unpublished.

RAC encourages data sharing but, in compliance with ethical principles, it does not demand the disclosure of any means of identifying research subjects, preserving the privacy of research subjects. The practice of open data is to enable the reproducibility of results, and to ensure the unrestricted transparency of the results of the published research, without requiring the identity of research subjects. 


\section{APPENDIX}

\section{Semi-Structured Interview Guide}

\section{The Research Goals}

- The paper's main goal is to investigate whether the management of prioritized policies in Brazil were in line with the worldwide movement known as boundarycrossing strategies;

- Then, three main comprehensive governmental programs of President Rousseff's first administration are analyzed in order to assess if their frameworks are (convergent) compatible with this movement. The policies were implemented at federal level — Brazil without Poverty Plan (BWP), Growth Acceleration Program (GAP), and Greater Brazil Plan (BBP), and cover initiatives in the social, infrastructure, and economic areas, respectively.

\section{The Program's Reasons}

1. The literature argues that boundary-crossing strategies stem from the reasons listed below. In your opinion, are these the reasons (causes of the program) the programs (BSM, PAC, or PBM) were created? If so, why? Apart from the issues listed, would you mention any other reasons for their development? If so, why?

a. Fragmentation or lack of coordination;

b. Complexity of public issues;

c. Better value (service outputs and outcomes);

d. Strategic management (synergies from working with other organizations, sectors, or levels of government).

\section{The Program and Post-NPM Trends}

2. Some of the post-New Public Management trends are mentioned in the literature as convergent with boundary-crossing strategies. Would you agree that the following principles and guidelines were also embedded in the design of the BSM, PAC, or PSM programs? Would you add any others?
a. Network;
b. Collaboration;
c. Control and coordination;
d. Integrated and holistic view of government;
e. Strengthening bureaucracy;
f. Leadership.

\section{The Program's Features}

3. Regarding general features, were the following factors part of the program's implementation and if so, how? Are there any other features that you would comment on?

a. Coordination by formal and informal instruments;

b. Long-term perspective;

c. Policy learning process.

\section{The Program's Goals}

4. Boundary-crossing strategies typically address a variety of objectives. Focusing on management, would you agree that the following were part of the programs goals? Would you add any others?

a. Increasing accountability;

b. Cooperation;

c. Better results;

d. Government coherence;

e. Performance monitoring.

5. Finally, in terms of management or policy implementation results, has the program accomplished these goals?

\section{Interview List}

1. Hébrida Moreira: General Coordinator of Sectoral Monitoring in the Secretary of Economic Policy of the Ministry of Finance

2. Inês Magalhães: National Secretary of Housing of the Ministry of Cities

3. Irani Ramos: Deputy Minister of the Ministry of National Integration

4. Jackson De Toni: Planning Manager of the Brazilian Agency for Industrial Development

5. Janine Melo: Program Director at the Ministry of Social Development

6. Juliano Pimentel: Advisor to the Chief of Staffs Office

7. Letícia Mendonça: Advisor to the Minister of Agrarian Development

8. Marcos Toscano: Deputy Executive Secretary of the Ministry of Science, Technology, and Innovation

9. Roberto Garibe: Advisor to the Chief of Staffs Office and Director of the Energy Infrastructure Sector of PAC at the Ministry of Planning 